\title{
Metal concentrations around thermal power plants, rural and urban areas using honeybees (Apis mellifera L.) as bioindicators
}

\author{
N. M. Zarić ${ }^{1}$ (D) K. Ilijević ${ }^{2}$ L. Stanisavljević ${ }^{3} \cdot$ I. Gržetić $^{2}$
}

Received: 19 February 2015/Revised: 27 August 2015/Accepted: 21 September 2015/Published online: 6 October 2015

(C) Islamic Azad University (IAU) 2015

\begin{abstract}
Honeybees are great bioindicators because they cover wide areas during their foraging activity. Our study included industrial, urban and rural region, where samples were taken in July and September. Industrial region with three apiaries in the area covered two thermal power plants, Kostolac A and B. Two apiaries covered a wide urban region of Belgrade, and the rural region consisting of mainly agricultural-woodland area near village Mesić was covered with one apiary. Aim of this study was to investigate the capability of bees as bioindicators to detect different concentrations of metals in foraging regions, during two sampling periods, and to compare concentrations of $\mathrm{Al}, \mathrm{Ba}, \mathrm{Cd}, \mathrm{Co}, \mathrm{Cr}, \mathrm{Cu}, \mathrm{Fe}, \mathrm{Li}, \mathrm{Mn}, \mathrm{Na}, \mathrm{Ni}, \mathrm{Pb}, \mathrm{Sr}$ and $\mathrm{Zn}$ found in their bodies. Significant differences were detected for $\mathrm{Al}, \mathrm{Ba}, \mathrm{Cr}, \mathrm{Cu}, \mathrm{Fe}, \mathrm{Li}$, and $\mathrm{Ni}$ between at least two analyzed regions. Significant differences in concentrations between sampling dates were found for $\mathrm{Al}, \mathrm{Ba}, \mathrm{Co}, \mathrm{Cr}$ and $\mathrm{Fe}$ in at least one of the locations. For $\mathrm{Cd}, \mathrm{Mn}, \mathrm{Na}, \mathrm{Pb}, \mathrm{Sr}$ and $\mathrm{Zn}$, no significant differences were found between locations or sampling dates, suggesting equal and stable levels of concentration for these elements in the environment.
\end{abstract}

N. M. Zarić

nzaric@tmf.bg.ac.rs

1 Innovation Center Faculty of Technology and Metallurgy, University of Belgrade, Karnegijeva 4, 11120 Belgrade, Serbia

2 Faculty of Chemistry, University of Belgrade, Studentski trg 16, 11000 Belgrade, Serbia

3 Faculty of Biology, University of Belgrade, Studentski trg 16, 11000 Belgrade, Serbia
Keywords Bioindicators - Metal pollution - Honeybee · Thermal power plant · Urban pollution - Rural pollution

\section{Introduction}

A constant increase in human population has led to the increase in anthropogenic pollution of the environment. Anthropogenic sources of pollution can be different: industry, traffic, urban development, intense agriculture, etc. All of these sources have a negative influence on the environment. Emitted dust, smoke, industrial and exhaust gases all heavily burden the atmosphere, soil, water and living organisms (Migula et al. 1991; Diels et al. 2002). One of the results of these processes is increasing metal concentrations in soil, water, air and other elements of the environment (Diels et al. 2002; Free et al. 1983; Wang et al. 2001).

Thermal power plants (TPP) have a long history of negative environmental impact due to their emission of particulate matter, inorganic and organic pollutants. During coal combustion, a significant amount of various metals, some of which are very toxic (such as $\mathrm{Pb}, \mathrm{Cd}, \mathrm{Hg}$ ), is emitted to the environment through different pathways. Numerous investigations and publications are already available, mainly elaborating monitoring results based on air and ash samples which were directly collected in the vicinity of the TPPs (Davison et al. 1974; Goodarzi 2006; Hower et al. 1996; Meij 1994, Meij and te Winkel 2007; Pavageau et al. 2002; Pudasainee et al. 2010).

Urban areas are burdened with pollution which comes from various sources. Traffic is one of the major pollution sources in city centers (Silva et al. 2014). Burning of coal, oil and natural gas for purposes of heating is another source of urban pollution (Junninen et al. 2009). 
As the population on the planet grows, so grows the need for food. To produce more food, farmers started using more fertilizers, herbicides, pesticides, fungicides and insecticides. Many of them leave metals as pollutants in the soil, air and water of agricultural areas (Mortvedt 1996).

Constantly growing pollution requires more sophisticated and efficient monitoring methods, such that can cover bigger areas, give faster results and cost less. Consequently, interest in use of bioindicators that own all these characteristics, for the detection and evaluation of environmental contaminants, has increased in the past few decades. Several different animal and plant species have been suggested as suitable for monitoring environmental pollution (Akguc et al. 2010; García-Hernández et al. 2015; Kaonga et al. 2010; Ugulu et al. 2012;). Since 1970, honeybees (Apis mellifera) have been increasingly used to monitor toxic metal environmental pollution (Bromenshenk et al. 1985; Crane 1984; Leita et al. 1996; Porrini et al. 2002).

Metals generally do not cause bee mortality, but they can accumulate in their body. Thus, the contamination in the form of metals accumulating in the honeybee's body may reflect the contamination of plants, soil, air and water in the areas that are covered by foraging activities of bees (Sadeghi et al. 2013). Suspended particulate matter (PM), originated from TPP fly ash, enrich the atmosphere and contaminate the ground surface with toxic metals present in ash. PM and toxic metals contained in it can directly deposit on the hairy body of the bees or can reach the insect by nectar, pollen, honeydew, or through the water they drink during foraging.

Honeybees have been proposed as suitable bioindicators of metal pollution by many researchers (Crane 1984; Leita et al. 1996; Perugini et al. 2011; Porrini et al. 2003; Raes et al. 1992; Sadeghi et al. 2013; Tong et al. 1975; Wallwork-Barber et al. 1982). Bees, as foragers, fly over a $7-\mathrm{km}^{2}$ area and usually complete $12-15$ foraging trips per day (Perugini et al. 2011). As suggested by Leita et al. (1996), a network of apiaries located within polluted areas can supply data for the constant monitoring of toxic metal emissions from either point or diffuse sources. Most of these results prove that bees are good bioindicators, but not many results demonstrate the capability of bees as bioindicators to significantly distinguish different concentrations of metals in different foraging regions.

All organisms have requirements for minerals which are essential for their growth and development, and honeybees are no different. Even newly emerged bees have same mineral content in their bodies (Black 2006). The mineral content in young bees can be related to the diet they were exposed to. But since they did not fly out of the hive, this content does not represent the full impact of the environment. Diet exposure is only one of the ways bees are exposed to the environment contamination. Some of the other ways bees accumulate contaminants are directly on their body, by water they drink, or by pollen and nectar they process. That is the reason why forager bees are selected for the analysis.

The aim of this study was to determine levels of $\mathrm{Al}, \mathrm{Ba}$, $\mathrm{Cd}, \mathrm{Co}, \mathrm{Cr}, \mathrm{Cu}, \mathrm{Fe}, \mathrm{Li}, \mathrm{Mn}, \mathrm{Na}, \mathrm{Ni}, \mathrm{Pb}, \mathrm{Sr}$ and $\mathrm{Zn}$ in bodies of honeybees in different time of year and at sampling sites characterized by different environmental impact. In this study, we determined impact of the environment on the contents of the analyzed elements in bodies of honeybees.

\section{Materials and methods}

\section{Sampling sites and sampling}

The research materials were samples of honeybees obtained from six stationary apiaries - three tightly bound to TPP Kostolac, two from the urban area of Belgrade (Capital of Serbia) and one from mainly agriculturalwoodland area near the village of Mesić (eastern border of Serbia with Romania).

\section{Kostolac (TPP)}

Kostolac is some $60 \mathrm{~km}$ to the East from Belgrade. Three apiaries (site number: 1, 2 and 3) are located around two thermal power plants located in municipality Kostolac, Braničevo district, Serbia (Fig. 1). The two power plants are roughly $3.5 \mathrm{~km}$ apart. This means that the bees from all apiaries are affected by both power plants. Sampling site 1 was $2 \mathrm{~km}$ to the south-southwest from thermal power plant Kostolac A, located in a small town of Kostolac, and $4.5 \mathrm{~km}$ southwest from thermal power plant Kostolac B. The sampling site is surrounded by mostly agricultural land. Sampling site 2 is in the village Drmno located $1.5 \mathrm{~km}$ to the south of power plant Kostolac B, and $4 \mathrm{~km}$ east from thermal power plant Kostolac A. The village is surrounded by an open pit coal mine. Sampling site 3 is located $1.7 \mathrm{~km}$ to the north-northeast of thermal power plant Kostolac A and $2.5 \mathrm{~km}$ to the northwest of thermal power plant Kostolac B. Ash disposal site for the two power plants is $500 \mathrm{~m}$ to the north-northwest of sampling site 3 . The area covered with these three apiaries is about $40 \mathrm{~km}^{2}$. Prevalent wind direction for TPP region during the sampling period is given in Fig. 2. Most frequent wind direction was southeast, and the second most frequent wind was north. 


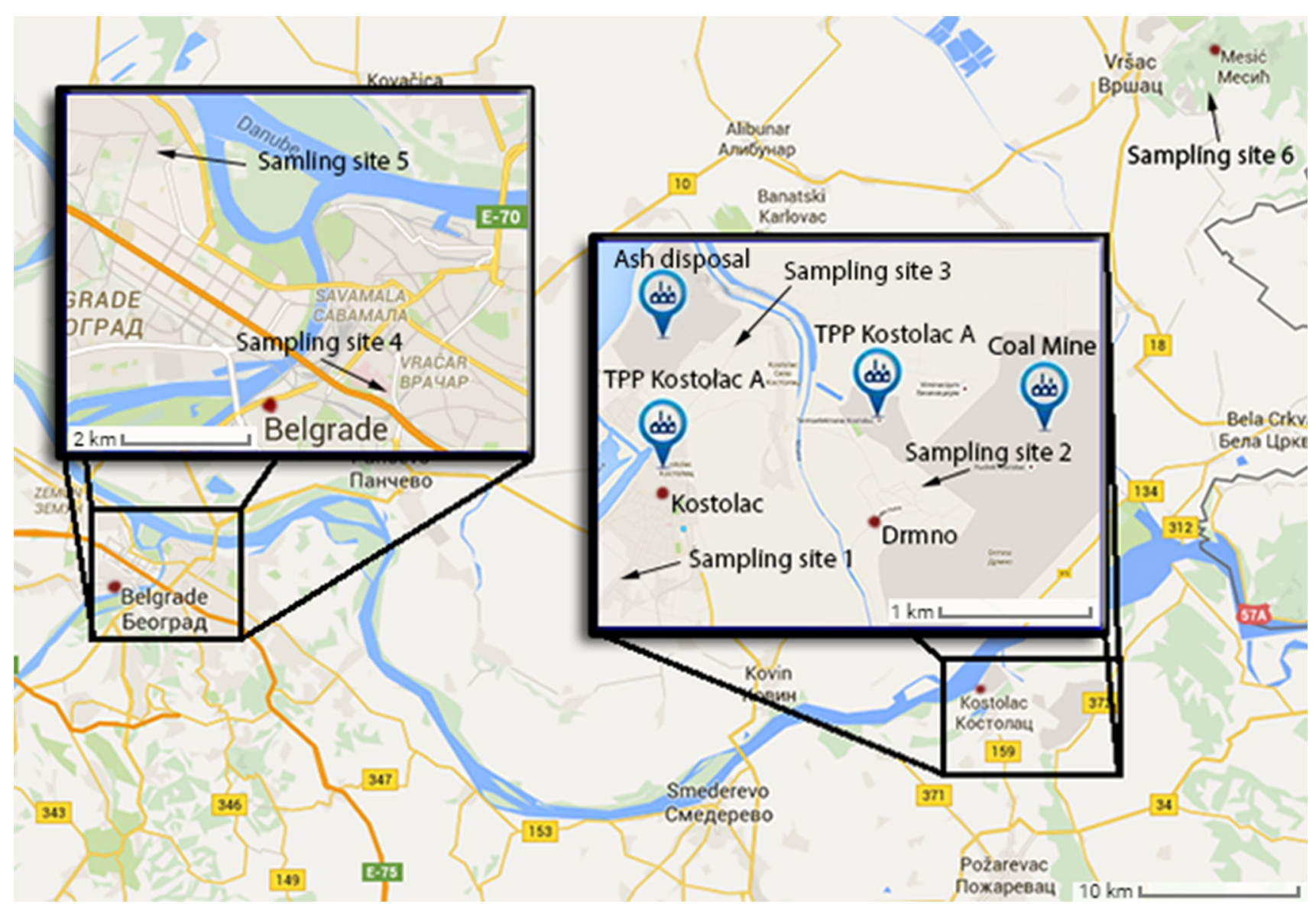

Fig. 1 Map of sampling sites

\section{Belgrade $(B G)$}

Two sampling sites (4 and 5) are located in the urban area of Belgrade (Fig. 1). Both of those sites are located in the center of the city. Sampling site 4 is located adjacent to a highway, and sampling site 5 is located in Zemun, northern part of the city. The distance between the sampling sites is $7 \mathrm{~km}$. Most frequent wind directions during the sampling period were west and northwest (Fig. 2).

Mesić (MS)

Sampling site (6), located near the small village Mesić, municipality Vršac, South Banat District, Serbia, contained one single apiary. The sampling locality is in a rural region containing mainly agricultural-woodland areas. To the north it is bordering a protected area, "Landscape of outstanding features 'Vršačke Planine." To the west vineyards cover an area of around 600 ha. From the other sides, it is surrounded by agricultural land.

Sampling was performed twice during 2014. The first sampling was done at the beginning of July and second at

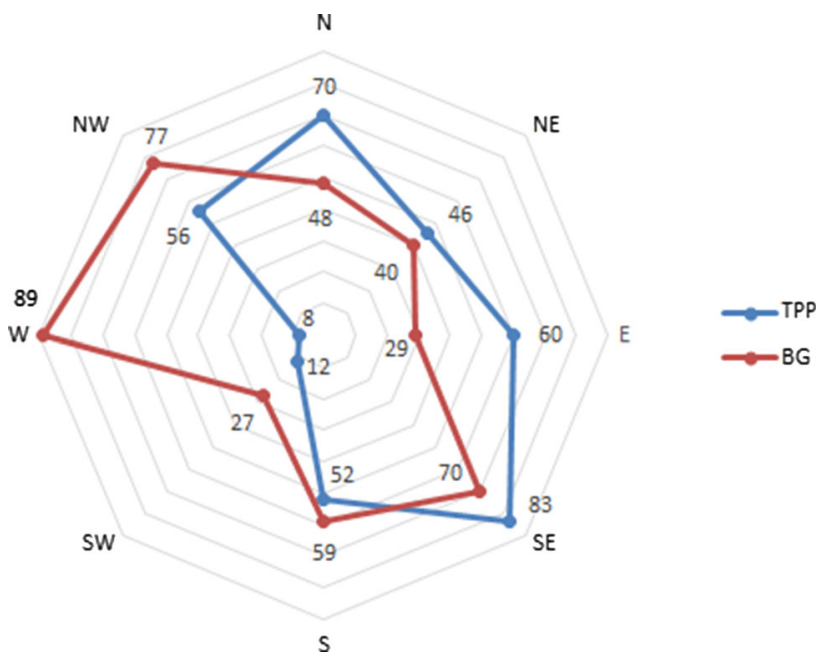

Fig. 2 Frequencies of prevalent wind directions during the sampling period for TPP and Belgrade (BG) urban region

the beginning of September. Samples were taken from two hives at each of the sampling sites, except at Mesić, where samples were taken from three hives. Between 5 and $10 \mathrm{~g}$ of sample (50-100 bees) was collected from the outer 
frame of the hive that was occupied with bees but without brood. Samples were directly transferred into sterile plastic containers. The collected bees were killed in the laboratory by instant freezing and kept at $-21 \pm 3{ }^{\circ} \mathrm{C}$ until analyzed.

\section{Sample preparation}

Frozen samples of bees were first dried in open air for $24 \mathrm{~h}$ to remove any residual ice. They were measured and dried in the oven at $60{ }^{\circ} \mathrm{C}$ until constant mass. A test portion of dried sample between 0.5 and 1.0 grams was taken and digested according to the US EPA SW-846 Method 3052, under high pressure in closed Teflon vessels, with $7 \mathrm{ml}$ of concentrated $\mathrm{HNO}_{3}$ and $2 \mathrm{ml}$ of concentrated $\mathrm{H}_{2} \mathrm{O}_{2}$. Mineralization was performed in a closed microwave digestion system (ETHOS 1, Advanced Microwave Digestion System, Milestone, Italy) by heating the samples up to $200{ }^{\circ} \mathrm{C}$ (15 min), followed by another $15 \mathrm{~min}$ at the same temperature. Each sample was cooled, transferred to a $25-\mathrm{mL}$ volumetric flask and diluted to $25 \mathrm{~mL}$ with deionized water.

\section{Instrumental analysis}

Quantitative determination of metals was performed by inductively coupled plasma-optical emission spectrometry, ICP-OES (iCAP 6500Duo, Thermo Scientific, Cambridge, UK). Multi-element standard solutions were used (MultiElement Plasma Standard Solution 4, Specpure ${ }^{\circledR}$ Alfa Aesar, Karlsruhe, Germany) for the determination of elements of interest. Quality control was based on the analysis of blanks (prepared following the whole sample preparation procedure), duplicates and analysis of the standard solutions (Rakić et al. 2013).

\section{Statistical analysis}

The results from analyses were statistically processed. Mean concentrations and standard deviations of elements concentrations for the three regions, over the entire study period, were calculated. The assessment of the data normality was done by Kolmogorov-Smirnov test. For some elements, data were not normally distributed; therefore, they were log-transformed and normality was reassessed. The results were processed by two-way analysis of variance (ANOVA), followed by Tukey's HSD (Honestly Significant Difference) multiple comparisons test. Differences in concentrations between dates or locations were considered significant if $p$ values were $\leq 0.05$. Differences in concentration between sampling sites within TPP region (sampling sites 1,2 and 3) and urban region (sampling sites 4 and 5) were also assessed.

\section{Results and discussion}

In the first step, concentrations of metals found in honeybee bodies were analyzed disregarding the sampling sites from which the bees were harvested. The range and the average values of analyzed metal concentrations are given in Table 1.

Most of analyzed metals are above detection limits. This is good indication that honeybees are excellent bioindicators for metal pollution of the environment.

A comparison of the results for individual sites, presented in Table 2 and Fig. 3, enables us to compare the levels of contamination and to determine whether statistically significant differences are present between metal concentrations determined in bees collected from agricultural-woodland (MS-Mesić) region, urban (BG-Belgrade) region and thermal power plant region (TPPKostolac). Bees from the same apiary may fly in different directions and sample different sites showing different levels of contamination (Formicki et al. 2013). This can explain relatively big standard deviations for the analyzed elements in this study.

$\mathrm{Na}$ has the highest concentration of all the elements discussed in this study. An average Na concentration was $426 \mathrm{mg} \mathrm{kg}^{-1}$. It is followed by $\mathrm{Fe}, \mathrm{Zn}, \mathrm{Al}, \mathrm{Mn}, \mathrm{Cu}, \mathrm{Sr}, \mathrm{Ba}$, $\mathrm{Ni}, \mathrm{Pb}, \mathrm{Cr}, \mathrm{Cd}, \mathrm{Co}$ and $\mathrm{Li}$. (Table 1).

Statistically significant differences between analyzed regions are represented by different uppercase letters in Fig. 3. Significant differences were found for $\mathrm{Al}, \mathrm{Ba}, \mathrm{Cr}$, $\mathrm{Cu}, \mathrm{Fe}, \mathrm{Li}$ and $\mathrm{Ni}$ between at least two of analyzed regions. $\mathrm{Cd}, \mathrm{Co}, \mathrm{Mn}, \mathrm{Na}, \mathrm{Pb}, \mathrm{Sr}$ and $\mathrm{Zn}$ showed no significant

Table 1 Range and mean concentrations of metals in adult honeybees $\left[\mathrm{mg} \mathrm{kg}^{-1}\right.$ dry matter (d.m.)]

\begin{tabular}{lll}
\hline Element & Range & $\bar{x}\left(\mathrm{mg} \mathrm{kg}^{-1}\right)$ \\
\hline $\mathrm{Al}$ & $6.8-327$ & 60 \\
$\mathrm{Ba}$ & $0.54-3.97$ & 2.00 \\
$\mathrm{Cd}$ & $0.046-0.33$ & 0.16 \\
$\mathrm{Co}$ & $0.076-0.26$ & 0.14 \\
$\mathrm{Cr}$ & $0.066-1.07$ & 0.22 \\
$\mathrm{Cu}$ & $11.8-29.2$ & 21.0 \\
$\mathrm{Fe}$ & $101-421$ & 188 \\
$\mathrm{Li}$ & $<\mathrm{DL}-0.24$ & 0.047 \\
$\mathrm{Mn}$ & $34-90$ & 54 \\
$\mathrm{Na}$ & $216-687$ & 426 \\
$\mathrm{Ni}$ & $0.25-2.16$ & 1.02 \\
$\mathrm{~Pb}$ & $<\mathrm{DL}-0.97$ & 0.31 \\
$\mathrm{Sr}$ & $1.17-3.55$ & 2.20 \\
$\mathrm{Zn}$ & $65-156$ & 100 \\
\hline
\end{tabular}

$D L$ detection limit 
Table 2 Minimum, maximum and mean metal concentrations in the bodies of honeybees ( $\mathrm{mg} \mathrm{kg}^{-1}$ d.m.) and standard deviation in samples from the three regions for the entire study period

\begin{tabular}{|c|c|c|c|c|c|c|c|c|c|c|c|c|}
\hline \multirow[t]{3}{*}{ Element } & \multicolumn{12}{|c|}{ Location } \\
\hline & \multicolumn{4}{|l|}{ TPP } & \multicolumn{4}{|l|}{ BG } & \multicolumn{4}{|l|}{ MS } \\
\hline & Min & Max & Mean & SD & Min & $\operatorname{Max}$ & Mean & $\mathrm{SD}$ & Min & Max & Mean & SD \\
\hline $\mathrm{Al}$ & 16 & 327 & 113 & 110 & 8.73 & 37.73 & 24.04 & 9.4 & 7 & 46 & 29 & 16 \\
\hline $\mathrm{Ba}$ & 0.55 & 3.40 & 1.74 & 0.97 & 1.36 & 3.10 & 1.99 & 0.70 & 2.20 & 3.97 & 2.77 & 0.70 \\
\hline $\mathrm{Cd}$ & 0.046 & 0.26 & 0.14 & 0.091 & 0.046 & 0.25 & 0.15 & 0.075 & 0.12 & 0.33 & 0.21 & 0.076 \\
\hline Co & 0.082 & 0.26 & 0.16 & 0.060 & 0.10 & 0.26 & 0.14 & 0.053 & 0.076 & 0.17 & 0.11 & 0.034 \\
\hline $\mathrm{Cr}$ & 0.084 & 1.07 & 0.36 & 0.32 & 0.089 & 0.22 & 0.15 & 0.047 & 0.10 & 0.28 & 0.15 & 0.068 \\
\hline $\mathrm{Cu}$ & 11.8 & 21.6 & 17.1 & 3.1 & 22.7 & 29.2 & 25.7 & 2.3 & 17.5 & 25.5 & 21.8 & 3.0 \\
\hline $\mathrm{Fe}$ & 118 & 421 & 247 & 115 & 124 & 220 & 169 & 37 & 105 & 219 & 139 & 43 \\
\hline $\mathrm{Li}$ & $<\mathrm{DL}$ & 0.24 & 0.092 & 0.080 & $<\mathrm{DL}$ & 0.042 & 0.014 & 0.020 & $<\mathrm{DL}$ & 0.090 & 0.032 & 0.033 \\
\hline $\mathrm{Mn}$ & 34 & 90 & 50 & 17 & 38.3 & 64.1 & 52.4 & 9.2 & 49.3 & 70.4 & 61.1 & 7.7 \\
\hline $\mathrm{Na}$ & 216 & 687 & 443 & 142 & 332 & 572 & 406 & 74 & 331 & 596 & 454 & 101 \\
\hline $\mathrm{Ni}$ & 0.25 & 1.94 & 0.86 & 0.48 & 0.40 & 0.90 & 0.71 & 0.18 & 1.33 & 2.16 & 1.76 & 0.33 \\
\hline $\mathrm{Pb}$ & 0.030 & 0.97 & 0.33 & 0.28 & 0.16 & 0.78 & 0.40 & 0.25 & $<\mathrm{DL}$ & 0.19 & 0.10 & 0.085 \\
\hline $\mathrm{Sr}$ & 1.47 & 3.55 & 2.39 & 0.70 & 1.39 & 2.89 & 2.14 & 0.54 & 2.00 & 2.32 & 2.17 & 0.16 \\
\hline $\mathrm{Zn}$ & 78 & 156 & 101 & 25 & 90 & 137 & 100 & 16 & 83 & 117 & 104 & 12 \\
\hline
\end{tabular}

$D L$ detection limit
Fig. 3 Mean concentration comparison of all analyzed elements for three regions: BG-urban region, MSagricultural-woodland region, TPP - thermal power plant region (shown in log scale). Different uppercase letters indicate per location statistically significant differences between metal concentrations over the entire study period

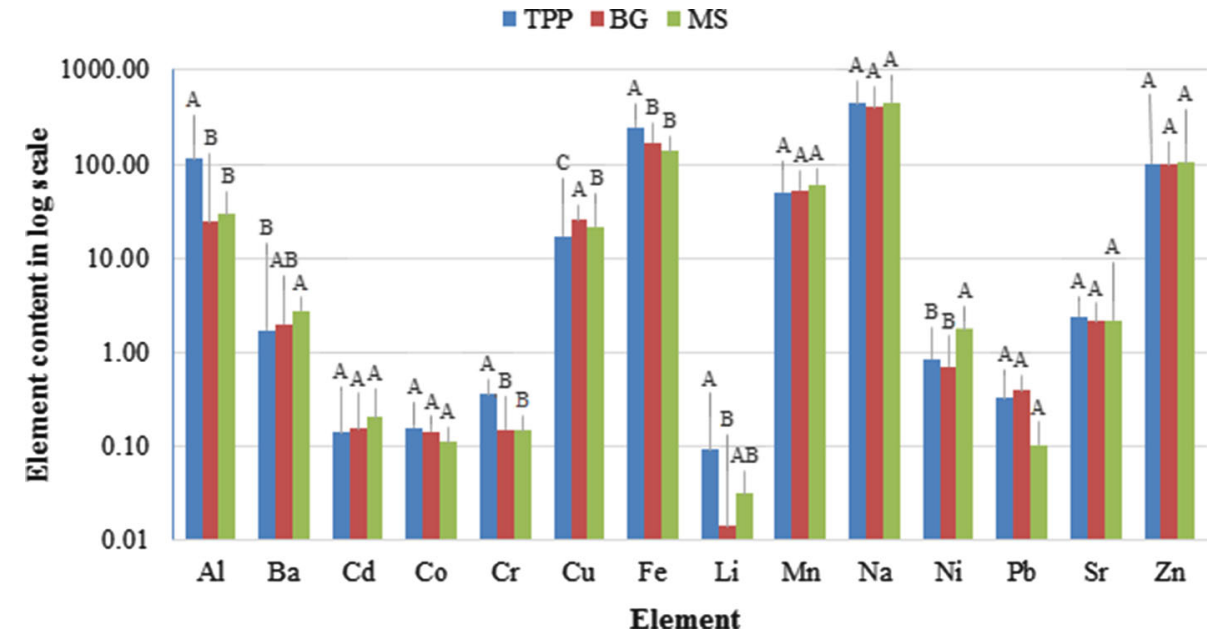

differences between analyzed regions. For Al, significant differences were found between the TPP region and agricultural-woodland region, as well as between TPP region and urban region. Mean concentration of $\mathrm{Al}$ was $113 \mathrm{mg} \mathrm{kg}{ }^{-1}$ d.m. in TPP region, $24.04 \mathrm{mg} \mathrm{kg}^{-1}$ d.m. in urban region, and $29 \mathrm{mg} \mathrm{kg}^{-1}$ d.m. in agricultural-woodland region. $\mathrm{Ba}$ shows significant differences between agricultural-woodland region and TPP region, with mean values of 2.77 and $1.74 \mathrm{mg} \mathrm{kg}^{-1}$ d.m., respectively. $\mathrm{Cr}$ showed significant differences between TPP region and other two regions agricultural-woodland region and urban region. The mean concentration of $\mathrm{Cr}$ in TPP region was $0.36 \mathrm{mg} \mathrm{kg}^{-1} \mathrm{~d}$.m. In urban and agricultural-woodland region, $\mathrm{Cr}$ had the same mean concentrations of
$0.15 \mathrm{mg} \mathrm{kg}^{-1}$ d.m. $\mathrm{Cu}$ showed significant differences between all three regions, TPP, urban and agriculturalwoodland region, with mean concentrations of 17.1, 25.7 and $21.8 \mathrm{mg} \mathrm{kg}^{-1}$ d.m., respectively. For $\mathrm{Fe}$, there were significant differences between the TPP region and agricultural-woodland region, and TPP and urban region. TPP region had the highest mean concentration of $\mathrm{Fe}$ which was $247 \mathrm{mg} \mathrm{kg}^{-1}$ d.m., followed by urban region with $169 \mathrm{mg} \mathrm{kg}^{-1}$ d.m. and agricultural-woodland region $139 \mathrm{mg} \mathrm{kg}^{-1}$ d.m. Li showed significant difference between TPP region and urban region, with mean concentrations of 0.092 and $0.014 \mathrm{mg} \mathrm{kg}^{-1}$ d.m., respectively. Statistically significant differences for $\mathrm{Ni}$ were found between agricultural-woodland region and TPP region, as 
well as between agricultural-woodland region and urban region. Mean Ni concentration in agricultural-woodland region was $1.76 \mathrm{mg} \mathrm{kg}^{-1}$ d.m., in urban region $0.71 \mathrm{mg} \mathrm{kg}^{-1}$ d.m. and in TPP region $0.86 \mathrm{mg} \mathrm{kg}^{-1}$ d.m. As mentioned above for $\mathrm{Cd}, \mathrm{Co}, \mathrm{Mn}, \mathrm{Na}, \mathrm{Pb}, \mathrm{Sr}$ and $\mathrm{Zn}$, no statistically significant differences were found. Explanation can be found in very similar environmental exposure of bees to these elements in the three regions examined in this study. Moreover, high standard deviations are present for some of the analyzed elements. Although high standard deviations were expected because of the nature of the bioindicators used, it should be mentioned that it can influence statistical analysis.

Statistically significant differences between samples collected at different dates in the study were found for $\mathrm{Al}$, $\mathrm{Ba}, \mathrm{Co}, \mathrm{Cr}, \mathrm{Cu}$ and $\mathrm{Fe}$, while no differences were detected for $\mathrm{Cd}, \mathrm{Li}, \mathrm{Mn}, \mathrm{Na}, \mathrm{Ni}, \mathrm{Pb}, \mathrm{Sr}$ and $\mathrm{Zn}$ (Table 3). For all of these elements, concentrations were higher in July than in September. This can be explained by higher bee activity during July. More plants are flowering and bees fly out more frequently to collect pollen and nectar, which makes them more exposed to environmental pollution. In September, fewer plants are in flower, and bees do not fly out as frequent, so they are less exposed to pollution. Also a reduction in the amounts of nectar and pollen coming into the hive causes reduced brood rearing and diminishing population. The proportion of old bees in the colony decreases (Kauffeld 1980). Along with the

Table 3 Mean concentrations of metal in bodies of honeybees $\left(\mathrm{mg} \mathrm{kg}^{-1}\right.$ d.m.) per location in July and September

\begin{tabular}{|c|c|c|c|c|c|c|}
\hline \multirow{2}{*}{$\begin{array}{l}\text { Month } \\
\text { Location }\end{array}$} & \multicolumn{3}{|l|}{ July } & \multicolumn{3}{|c|}{ September } \\
\hline & TPP & BG & MS & TPP & BG & MS \\
\hline \multicolumn{7}{|l|}{ Element } \\
\hline $\mathrm{Al}$ & $200^{\mathrm{Aa}}$ & $32^{\mathrm{Aa}}$ & $24^{\mathrm{Aa}}$ & $40^{\mathrm{Bb}}$ & $17^{\mathrm{Ab}}$ & $36^{\mathrm{Ab}}$ \\
\hline $\mathrm{Ba}$ & $2.56^{\mathrm{Aa}}$ & $2.48^{\mathrm{Aa}}$ & $2.31^{\mathrm{Aa}}$ & $0.99^{\mathrm{Bb}}$ & $1.50^{\mathrm{Ab}}$ & $3.07^{\mathrm{Ab}}$ \\
\hline $\mathrm{Cd}$ & $0.089^{\mathrm{Aa}}$ & $0.12^{\mathrm{Aa}}$ & $0.25^{\mathrm{Aa}}$ & $0.16^{\mathrm{Aa}}$ & $0.19^{\mathrm{Aa}}$ & $0.16^{\mathrm{Aa}}$ \\
\hline Co & $0.22^{\mathrm{Aa}}$ & $0.16^{\mathrm{Aa}}$ & $0.13^{\mathrm{Aa}}$ & $0.11^{\mathrm{Bb}}$ & $0.13^{\mathrm{Ab}}$ & $0.097^{\mathrm{Ab}}$ \\
\hline $\mathrm{Cr}$ & $0.63^{\mathrm{Aa}}$ & $0.19^{\mathrm{Aa}}$ & $0.12^{\mathrm{Aa}}$ & $0.13^{\mathrm{Bb}}$ & $0.11^{\mathrm{Ab}}$ & $0.18^{\mathrm{Ab}}$ \\
\hline $\mathrm{Cu}$ & $19.1^{\mathrm{Aa}}$ & $27.0^{\mathrm{Aa}}$ & $23.1^{\mathrm{Aa}}$ & $15.3^{\mathrm{Ab}}$ & $24.4^{\mathrm{Ab}}$ & $20.4^{\mathrm{Ab}}$ \\
\hline $\mathrm{Fe}$ & $350^{\mathrm{Aa}}$ & $194^{\mathrm{Aa}}$ & $118^{\mathrm{Aa}}$ & $154^{\mathrm{Bb}}$ & $143^{\mathrm{Ab}}$ & $159^{\mathrm{Ab}}$ \\
\hline $\mathrm{Li}$ & $0.14^{\mathrm{Aa}}$ & $0.020^{\mathrm{Aa}}$ & $0.020^{\mathrm{Aa}}$ & $0.046^{\mathrm{Aa}}$ & $0.0091^{\mathrm{Aa}}$ & $0.043^{\mathrm{Aa}}$ \\
\hline $\mathrm{Mn}$ & $54^{\mathrm{Aa}}$ & $53^{\mathrm{Aa}}$ & $66^{\mathrm{Aa}}$ & $48^{\mathrm{Aa}}$ & $52^{\mathrm{Aa}}$ & $56^{\mathrm{Aa}}$ \\
\hline $\mathrm{Na}$ & $480^{\mathrm{Aa}}$ & $429^{\mathrm{Aa}}$ & $376^{\mathrm{Aa}}$ & $389^{\mathrm{Aa}}$ & $382^{\mathrm{Aa}}$ & $533^{\mathrm{Aa}}$ \\
\hline $\mathrm{Ni}$ & $1.04^{\mathrm{Aa}}$ & $0.79^{\mathrm{Aa}}$ & $1.74^{\mathrm{Aa}}$ & $0.67^{\mathrm{Aa}}$ & $0.62^{\mathrm{Aa}}$ & $1.78^{\mathrm{Aa}}$ \\
\hline $\mathrm{Pb}$ & $0.34^{\mathrm{Aa}}$ & $0.60^{\mathrm{Aa}}$ & $0.15^{\mathrm{Aa}}$ & $0.38^{\mathrm{Aa}}$ & $0.20^{\mathrm{Aa}}$ & $0.062^{\mathrm{Aa}}$ \\
\hline $\mathrm{Sr}$ & $2.45^{\mathrm{Aa}}$ & $2.28^{\mathrm{Aa}}$ & $2.00^{\mathrm{Aa}}$ & $2.15^{\mathrm{Aa}}$ & $1.99^{\mathrm{Aa}}$ & $2.28^{\mathrm{Aa}}$ \\
\hline $\mathrm{Zn}$ & $103^{\mathrm{Aa}}$ & $104^{\mathrm{Aa}}$ & $103^{\mathrm{Aa}}$ & $94^{\mathrm{Aa}}$ & $96^{\mathrm{Aa}}$ & $104^{\mathrm{Aa}}$ \\
\hline
\end{tabular}

Different uppercase letters indicate per location statistically significant differences between metal concentrations in samples taken in July and September Different lowercase letters indicate statistically significant differences between metal concentrations in samples taken in July and September independent of location decrease in the old bee population, their percentage in the analyzed sample also decreases, and that can also lead to lower concentration of analyzed elements in September compared to July.

\section{TPP region}

TPP region had significantly higher concentrations of $\mathrm{Al}$, $\mathrm{Cr}$ and $\mathrm{Fe}$ compared to both other regions, and higher $\mathrm{Li}$ concentrations compared to urban region. At the same time, it had significantly lower concentrations of $\mathrm{Ba}$ and $\mathrm{Ni}$ compared to agricultural-woodland region, and $\mathrm{Cu}$ when compared to both other regions. The fly ash produced by TPP Kostolac has the highest concentrations of $\mathrm{Al}$ and $\mathrm{Fe}$, compared to other analyzed elements by Popović et al. (2011). This study showed the same results (Table 2). The concentrations of $\mathrm{Al}, \mathrm{Cr}$ and $\mathrm{Fe}$ leached from the TPP Kostolac fly ash are positively correlated with each other (Popović et al. 2011). These elements are also positively correlated in the bees from this region analyzed in this study (Table 4). The ratios between leached $\mathrm{Al}, \mathrm{Cr}$ and $\mathrm{Fe}$ found in Popović's data were not the same as the ratios in this study, but they show a similar pattern, with Fe being the most abundant among them, followed by $\mathrm{Al}$ and with very small amounts of $\mathrm{Cr}$ compared to the first two. This shows that higher concentrations of $\mathrm{Al}, \mathrm{Cr}$ and $\mathrm{Fe}$ in this region came possibly from fly ash produced by power plants Kostolac A and B.

Higher concentrations of $\mathrm{Al}, \mathrm{Cr}$ and $\mathrm{Fe}$ in TPP region can influence living organisms. Since $\mathrm{Al}$ is not a proven nutrient for living organism, its higher concentrations could be toxic. Al toxicity to plants is largely dependent on soil $\mathrm{pH}$. Soil with low $\mathrm{pH}$ contains more dissolved $\mathrm{Al}$ ions. For this reason, certain crops cannot be grown on acid soils. However, there are some plants that are known as "aluminum accumulators" and may contain as much as $37 \%$ aluminum in ash (Foy et al. 1967). Inhalation of Al containing dust can cause lung problems in animals and humans (Burge et al. 2000). Nervous system of animals and humans is also sensitive to aluminum toxicity and may cause Alzheimer's disease (Iregren et al. 2001). High concentrations of $\mathrm{Cr}$ can also be toxic to plants. It can

Table 4 Correlation coefficient $(r)$ for $\mathrm{Al}, \mathrm{Cr}$ and $\mathrm{Fe}$ found in bodies of honeybees from TPP region

\begin{tabular}{llll}
\hline & $\mathrm{Al}$ & $\mathrm{Cr}$ & $\mathrm{Fe}$ \\
\hline $\mathrm{Al}$ & & $r=0.79^{* *}$ & $r=0.94^{* *}$ \\
$\mathrm{Cr}$ & $r=0.79^{* *}$ & & $r=0.72^{*}$ \\
$\mathrm{Fe}$ & $r=0.94^{* *}$ & $r=0.72^{*}$ & \\
\hline
\end{tabular}

* Correlation coefficient significant at a level of $p<0.05$

** Correlation coefficient significant at a level of $p<0.01$ 
effect plants growth and development including growth of roots, stems and leaves. $\mathrm{Cr}$ also has negative effects on plant physiological processes such as photosynthesis, water relations and mineral nutrition (Shanker et al. 2005). For mammals, $\mathrm{Cr}$ is an essential element that is required for normal sugar and fat metabolism. Cr toxicity is characterized by changes in the lungs, kidneys and liver. The lungs are affected with hyperemia, erosion and an inflammatory change in the respiratory system mucosa, or even nose septum perforation (Lee et al. 2002). It can also cause small cell cancer of the lung tissue (Park and Stayner 2006). Fe is an essential nutrient needed to produce chlorophyll in plants (Hänsch and Mendel 2009), while in animals it can be found in hemoglobin, myoglobin, cytochromes, iron-containing enzymes and in iron storage proteins, ferritin and hemosiderin. Although $\mathrm{Fe}$ is an essential element for living organisms, it can be toxic at higher concentrations. Fe toxicity to plants is mainly consequence of free radical production that irreversibly impairs cellular structure and damages membranes, DNA and proteins (de Dorlodot et al. 2005). Fe toxicity can also cause reduction in plant photosynthesis, yield and increase oxidative stress (Sinha et al. 1997). In humans and animals, Fe toxicity is not very frequent, but when it happens it can cause liver and heart disease, neurodegenerative disorder, hormonal abnormalities and immune system abnormalities (Berg et al. 2001; Wilkinson 1996; Walker and Walker 2000).

Within TPP region, there were three sampling sites: 1,2 and 3. $\mathrm{Cd}, \mathrm{Mn}$ and $\mathrm{Zn}$ showed statistically significant differences among sampling sites in TPP region. $\mathrm{Cd}$ had higher concentrations at sampling site 3 compared to sampling site 2 . Mn had significantly higher concentrations at sampling site 1 when compared to both of the other sampling sites in this region, and $\mathrm{Zn}$ had higher concentrations at sampling site 1 when compared to sampling site 2. Since $\mathrm{Mn}$ and $\mathrm{Zn}$ had higher concentrations at sampling site 1 which is not located in the direction of prevalent winds, it cannot be concluded that wind direction had a determining impact on the distribution of the analyzed elements within this region.

Significant differences between two sampling periods for TPP region were found for $\mathrm{Al}, \mathrm{Ba}, \mathrm{Co}, \mathrm{Cr}$ and $\mathrm{Fe}$ (Table 3). All of these elements had significantly higher values in July compared to September.

\section{Urban region (BG)}

The urban region (BG) had significantly higher concentration of $\mathrm{Cu}$ compared to TPP and agricultural-woodland region. At the same time, it had significantly lower concentrations of $\mathrm{Al}, \mathrm{Cr}, \mathrm{Fe}$ and $\mathrm{Li}$ compared to TPP region, and lower $\mathrm{Ni}$ concentration compared to agriculturalwoodland region (Fig. 3). Presence of $\mathrm{Cu}$ in urban areas is usually explained with anthropogenic and industrial activities. Significant source of $\mathrm{Cu}$ is vehicle brake pads. Recent study by Whiley (2011) revealed that the average copper content in brake pads, based on a broad spectrum of manufacturers and vehicle models analysis, varied between 4 and $12 \%$. Constant use of brakes in urban traffic is actually the major source of $\mathrm{Cu}$ in urban environments (Christoforidis and Stamatis 2009; Ho and Tai 1988; Li et al. 2001).

$\mathrm{Cu}$ is an essential element for living organism (Hänsch and Mendel 2009). In plants, animals and humans, it plays an important role in many enzymes. However, excessive absorption of $\mathrm{Cu}$ can be toxic to plants, affecting growth, root elongation and mitosis (Fargasova 2001; Ebbs and Kochian 1997). Chronic $\mathrm{Cu}$ poisoning is rear in humans and is mainly associated with liver damage. Acute $\mathrm{Cu}$ poisoning can cause abdominal pain, cramps, nausea, diarrhea and vomiting (Fraga 2005).

Urban region contained two sampling sites: 4 and 5 . Almost uniform distribution of elements was shown within this region. Significant difference was noticed only for $\mathrm{Li}$ which had higher concentrations at sampling site 5 which is located in the direction of prevalent wind. However, only one element is not enough to conclude that wind direction has influence on the distribution of analyzed elements within this region.

There were no significant differences in concentrations of elements analyzed between sampling dates in this region.

\section{Agricultural-woodland region (MS)}

The agricultural-woodland region (MS) had significantly higher concentrations of $\mathrm{Ni}$ when compared to TPP and urban region. It had higher concentrations of $\mathrm{Ba}$ and $\mathrm{Cu}$ when compared to TPP region, while at the same time significantly lower concentrations of $\mathrm{Al}, \mathrm{Cr}$ and $\mathrm{Fe}$ in relation to TPP region and $\mathrm{Cu}$ compared to urban region. It has been found that $\mathrm{Ni}$ concentrations in this study are highest in agricultural-woodland region. $\mathrm{Ni}$ can be found in some commercial phosphate fertilizers, as well as in animal manure that is the main organic fertilizer (Cordell et al. 2011; Gonnelli and Renella 2013; Mortvedt 1996; Smolders and Mertens 2013; Westfall et al. 2005). The use of barium fluorosilicate and carbonate as insecticides contributes to the presence of $\mathrm{Ba}$ in agricultural soils (Meister 2004). The vineyards in the vicinity to sampling site 6 located in agriculturalwoodland region are treated with Bordeaux mixture, which is used as a fungicide. The main component of 
this mixture is copper sulfate. Constant use of fertilizers, fungicides and insecticides in the area of Mesić can easily explain why the concentrations of $\mathrm{Ba}, \mathrm{Cu}$ and $\mathrm{Ni}$ in this region are high.

$\mathrm{Ni}$ is a part of metalloenzyme urease that can be found in plants, animals and humans; therefore, it is considered to be an essential element (Hänsch and Mendel 2009). In higher concentrations, it can be toxic to plants causing chlorosis and necrosis, disorder of cell membrane functions and changes in water balance (Rahman et al. 2005; Gonnelli et al. 2001). Since higher Ni concentrations are found in prevalently agricultural region and the origin of $\mathrm{Ni}$ could be related to the application of the fertilizers, farmers should pay attention to Ni contents in fertilizers to avoid elevated concentrations of $\mathrm{Ni}$ in crops. The toxicity of $\mathrm{Ni}$ in animals and humans could be manifested by its interference with normal physiological roles of $\mathrm{Mg}, \mathrm{Zn}, \mathrm{Ca}$ and Mn (Alcon et al. 1991). Ni can also cause increase in immunoglobulins and serum proteins concentrations (Bencko et al. 1986).

In agricultural-woodland region, no significant differences were shown between sampling dates.

All of the bee colonies that were used for sampling survived the season of bee activity. This means that the concentrations of elements detected in this study, although high, did not affect the viability of the bee colonies from which the samples were taken.

\section{Comparison with literature data}

Measured concentrations of $\mathrm{Ba}, \mathrm{Cd}, \mathrm{Co}, \mathrm{Cr}, \mathrm{Cu}, \mathrm{Mn}, \mathrm{Pb}$ and $\mathrm{Zn}$ in this study had values (Table 1) that fall in the range of values reported in previous studies (Bromenshenk et al. 1985; Conti and Botré 2001; Fakhimzadeh and Lodenius 2000; Porrini et al. 2002; Roman 2005, 2010; Sadeghi et al. 2013; van der Steen et al. 2012). Concentrations of $\mathrm{Al}, \mathrm{Fe}, \mathrm{Na}$ and $\mathrm{Ni}$ found in this study are higher than values reported in earlier studies. The Al concentrations in this study [6.8-327 $\mathrm{mg} \mathrm{kg}^{-1}$ d.m. (Table 1)] are significantly higher than the ones reported by van der Steen et al. (2012) who has found them to be in the range 4.6-15.52 mg kg ${ }^{-1}$ d.m. Fe concentration in earlier studies was below $117.12 \mathrm{mg} \mathrm{kg}^{-1}$ d.m. (Zhelyazkova et al. 2010), but this study shows that Fe concentrations are almost always above those levels and vary from 101 to $421 \mathrm{mg} \mathrm{kg}^{-1}$ d.m. A. Sadeghi et al. (2013) reported Na concentrations that varied from 12.65 to $16.18 \mathrm{mg} \mathrm{kg}^{-1}$ d.m. In this study, $\mathrm{Na}$ concentrations were reported to be much higher (216-687 mg kg${ }^{-1}$ d.m.). Ni concentrations in this study $\left(0.25-2.16 \mathrm{mg} \mathrm{kg}^{-1}\right.$ d.m.) are higher than the ones reported in previous studies where $\mathrm{Ni}$ concentrations varied from 0.12 to $0.50 \mathrm{mg} \mathrm{kg}^{-1}$ d.m. (Roman 2005; Porrini et al. 2002).

\section{Conclusion}

This study showed that concentrations of some of the analyzed elements ( $\mathrm{Al}, \mathrm{Ba}, \mathrm{Cr}, \mathrm{Cu}, \mathrm{Fe}, \mathrm{Li}$ and $\mathrm{Ni}$ ) were significantly different among considered TPP, urban and agricultural-woodland regions, while the concentrations of rest of the analyzed elements were not significantly different. Similar concentrations of some elements indicate that the environmental exposure of honeybees to these metals is very similar in the three regions. Also most of elements did not show temporal differences suggesting that their concentrations do not depend on the time of sampling.

For $\mathrm{Al}, \mathrm{Ba}, \mathrm{Cr}, \mathrm{Cu}, \mathrm{Fe}, \mathrm{Li}$ and $\mathrm{Ni}$, significant differences were observed between at least two of the analyzed regions. The TPP region had the highest concentrations of $\mathrm{Al}, \mathrm{Cr}, \mathrm{Fe}$ and $\mathrm{Li}$, which are the constituents of fly ash produced by TPP. The agricultural-woodland region had significantly higher concentrations of $\mathrm{Ni}, \mathrm{Ba}$ and $\mathrm{Cu}$, which were attributed to the use of artificial fertilizers, fungicides and insecticides. The urban region had highest concentration of $\mathrm{Cu}$. Elevated $\mathrm{Cu}$ concentrations in urban areas are related to intensive traffic, because $\mathrm{Cu}$ is one of constituents of brake pads, which emit considerable amount of this metal via aerosol particles into the atmosphere.

Significant differences between the two sampling dates were found in only one region, TPP region. $\mathrm{Al}, \mathrm{Ba}, \mathrm{Co}, \mathrm{Cr}$ and $\mathrm{Fe}$ in TPP region had significantly higher concentrations in July, which can be contributed to higher bee activity during this period.

The results in this study show that each region has specific pollution associated with anthropogenic activities that take place in it.

It can be concluded that honeybees are excellent bioindicators that can detect trace elements present in the environment. They are capable of distinguishing different concentrations of metals in different foraging regions.

Acknowledgments This paper was realized as part of project No. 176006, which was financed by the Ministry of Education, Science and Technological Development of the Republic of Serbia.

\section{References}

Akguc N, Ozyigit II, Yasar U, Leblebici Z, Yarci C (2010) Use of pyracantha coccinea Roem. as a possible biomonitor for the selected heavy metals. Int J Environ Sci Technol 7(3):427-434

Alcon MP, Arola L, Mas A (1991) Response to acute nickel toxicity in rats as a function of sex. Biol Met 4(3):136-140

Bencko V, Wagner V, Wagnerova M, Zavazal V (1986) Human exposure to nickel and cobalt: biological monitoring and immunobiological response. Environ Res 40:399-410

Berg D, Gerlach M, Youdim MB, Double KL, Zecca L, Riederer P, Becker G (2001) Brain iron pathways and their relevance to Parkinson's disease. J Neurochem 79:225-236 
Black J (2006) Review of honeybee nutrition research and practices. Rural Industries Research and Development Corporation, Australia, pp 32-35

Bromenshenk JJ, Carlson SR, Simpson JC, Thomas JM (1985) Pollution monitoring of Puget Sound with honeybees. Science 227(4687):632-634

Burge PS, Scott JA, McCoach J (2000) Occupational asthma caused by aluminum. Allergy 55(8):779-780

Christoforidis A, Stamatis N (2009) Heavy metal contamination in street dust and roadside soil along the major national road in Kavala's region, Greece. Geoderma 151(3-4):257-263

Conti ME, Botré F (2001) Honeybees and their products as potential bio-indicators of heavy metal contamination. Environ Monit Assess 69(3):267-282

Cordell D, Rosemarin A, Schröder JJ, Smit AL (2011) Towards global phosphorus security: a systems framework for phosphorus recovery and reuse options. Chemosphere 84(6):747-758

Crane E (1984) Bees, honey and pollen as indicators of metals in the environment. Bee World 65(1):47-49

Davison RL, Natusch DFS, Wallace JR, Evans CA Jr (1974) Trace elements in fly ash dependence of concentration on particle size. Environ Sci Technol 8(13):1107-1113

de Dorlodot S, Lutts S, Bertin P (2005) Effects of ferrous iron toxicity on the growth and mineral composition of an inter specific rice. J Plant Nutr 28:1-20

Diels L, Van Der Lelie N, Bastiaens L (2002) New developments in treatment of heavy metal contaminated soils. Environ Sci Biotechnol 1(1):75-82

Ebbs SD, Kochian LV (1997) Toxicity of zinc and copper to Brassica species: implications for phytoremediation. J Environ Qual 26:776-781

Fakhimzadeh K, Lodenius M (2000) Heavy metals in Finnish honey, pollen and honey bees. Apiacta 35:85-95

Fargasova A (2001) Phytotoxic effects of $\mathrm{Cd}, \mathrm{Zn}, \mathrm{Pb}, \mathrm{Cu}$ and $\mathrm{Fe}$ on Sinapis alba L. seedling and their accumulation in roots and shoots. Biol Plant 44:471-473

Formicki G, Greń A, Stawarz R, Zyśk B, Gał A (2013) Metal content in honey, propolis, wax, and bee pollen and implications for metal pollution monitoring. Pol J Environ Stud 22(1):99-106

Foy CD, Fleming AL, Burns GR, Armiger WH (1967) Characterization of differential aluminum tolerance among varieties of wheat and barley. Soil Sci Soc Am Proc 31:513-521

Fraga CG (2005) Relevance, essentiality and toxicity of trace elements in human health. Mol Aspects Med 25(4-5):235-244

Free JB, Williams IH, Pinset RJFH, Townshend A, Basi MS, Graham CL (1983) Using foraging honeybees to sample an area for trace metals. Environ Int 9(1):9-12

García-Hernández J, Hurtado LA, Leyva-García G, Güido-Moreno A, Aguilera-Márquez D, Mazzei V, Ferrante M (2015) Isopods of the genus Ligia as potential biomonitors of trace metals from the Gulf of California and pacific coast of the Baja California peninsula. Ecotox Environ Safe 112:177-185

Gonnelli C, Renella G (2013) Chromium and nickel. In: Alloway BJ (ed) Heavy metals in soils, 22. Springer, Netherlands, pp 313-333

Gonnelli C, Galardi F, Gabbrielli R (2001) Nickel and copper tolerance in three Tuscan populations of Silene paradoxa. Physiol Planta 113:507-514

Goodarzi F (2006) Characteristics and composition of fly ash from Canadian coal-fired power plants. Fuel 85(10-11):1418-1427

Hänsch R, Mendel RR (2009) Physiological functions of mineral micronutrients $(\mathrm{Cu}, \mathrm{Zn}, \mathrm{Mn}, \mathrm{Fe}, \mathrm{Ni}, \mathrm{Mo}, \mathrm{B}, \mathrm{Cl})$. Curr Opin Plant Biol 12(3):259-266

Ho YB, Tai KM (1988) Elevated levels of lead and other metals in roadside soil and grass and their use to monitor aerial metal depositions in Hong Kong. Environ Pollut 49(1):37-51
Hower JC, Robertson JD, Thomas GA, Wong AS, Schram WH, Graham UM, Rathbone RF, Robl TL (1996) Characterization of fly ash from Kentucky power plants. Fuel 75(4):403-411

Iregren A, Sjogren B, Gustafsson K, Hagman M, Nylén L, Frech W, Andersson M, Ljunggren KG, Wennberg A (2001) Effect on the nervous system in different groups of workers exposed to aluminum. Occup Environ Med 58(7):453-460

Junninen H, Mønster J, Rey M, Cancelinha J, Douglas K, Duane M, Forcina V, Müller A, Lagler F, Marelli L, Borowiak A, Niedzialek J, Paradiz B, Mira-Salama D, Jimenez J, Hansen U, Astorga C, Stanczyk K, Viana M, Querol X, Duvall RM, Norris GA, Tsakovski S, Wåhlin P, Hoŕak J, Larsen BR (2009) Quantifying the impact of residential heating on the urban air quality in a typical European coal combustion region. Environ Sci Technol 43(20):7964-7970

Kaonga CC, Kumwenda J, Mapoma HT (2010) Accumulation of lead, cadmium, manganese, copper and zinc by sludge worms; Tubifex tubifex in sewage sludge. Int $\mathrm{J}$ Environ Sci Technol 7(1):119-126

Kauffeld NM (1980) Seasonal cycle of activities in honey bee colonies. Beekeeping in the United States, agriculture handbook 335. USDA, Washington DC, pp 30-32

Lee CR, Yoo CI, Lee JH, Kang SK (2002) Nasal septum perforation of welders. Ind Health 40:286-289

Leita L, Muhlbachova G, Cesco S, Barbattini R, Mondini C (1996) Investigation on the use of honeybees and honeybee products to assess heavy metals contamination. Environ Monit Assess 43(1):1-9

Li X, Poon C, Liu PS (2001) Heavy metal contamination of urban soils and street dusts in Hong Kong. Appl Geochem 16(11-12):1361-1368

Meij R (1994) Trace element behavior in coal-fired power plants. Fuel Process Technol 39(1-3):199-217

Meij R, Te Winkel H (2007) The emissions of heavy metals and persistent organic pollutants from modern coal-fired power stations. Atmos Environ 41(40):9262-9272

Meister RT (2004) Crop protection handbook. Meister Media Worldwide, Willoughby

Migula P, Kafel A, Kedziorski A, Marczak G, Nakonieczny M (1991) Heavy metals in nectar flows, products and bees' tissues from industrialized regions. XXVIIIth Scientific Apicultural Conference, Puławy

Mortvedt JJ (1996) Heavy metal contaminants in inorganic and organic fertilizers. Fert Res 43(1-3):55-61

Park RM, Stayner LT (2006) A search for thresholds and other nonlinearities in the relationship between hexavalent chromium and lung cancer. Risk Anal 26(1):79-88

Pavageau M-P, Pécheyran C, Krupp EM, Morin A, Donard OFX (2002) Volatile metal species in coal combustion flue gas. Environ Sci Technol 36(7):1561-1573

Perugini M, Manera M, Grotta L, Abete MC, Tarasco R (2011) Heavy metal $(\mathrm{Hg}, \mathrm{Cr}, \mathrm{Cd}$, and $\mathrm{Pb})$ contamination in urban areas and wildlife reserves: honeybees as bioindicators. Biol Trace Elem Res 140(2):170-176

Popović A, Đorđević D, Relić D, Mihajlidi-Zelić A (2011) Speciation of trace and major elements from coal combustion products of serbian power plants (I)_ “Kostolac A" power plant. Energy Sources Part A 33:1960-1968

Porrini C, Ghini S, Girotti S, Sabatini AG, Gattavecchia E, Celli G (2002) Use of honeybees as bioindicators of environmental pollution in Italy. In: Deville's J, Pham-Delegate MH (eds) Honey bees: estimating the environmental impact of chemicals. Taylor \& Francis, London, New York, pp 186-247

Porrini C, Sabatini AG, Girotti S, Ghini S, Medrzycki P, Grillenzoni F, Bortolotti L, Gattavecchia E, Celli G (2003) Honeybees and 
bee products as monitors of the environmental contamination. Apiacta 38:63-70

Pudasainee D, Kim J-H, Lee S-H, Park J-M, Jang H-N, Song G-J, Seo Y-C (2010) Hazardous air pollutants emission from coal and oilfired power plants. Asia-Pac J Chem Eng 5(2):299-303

Raes H, Cornelis R, Rzeznik U (1992) Distribution, accumulation and depuration of administered lead in adult honeybees. Sci Total Environ 113(3):269-279

Rahman H, Sabreen S, Alam S, Kawai S (2005) Effects of nickel on growth and composition of metal micronutrients in barley plants grown in nutrient solution. J Plant Nutri 28:393-404

Rakić T, Ilijević K, Lazarević M, Gržetić I, Stevanović V, Stevanović B (2013) The resurrection flowering plant Ramonda nathaliae on serpentine soil-coping with extreme mineral element stress. Flora 208(10-12):618-625

Roman A (2005) The influence of environment on accumulation of toxic elements in honey bees' body. Proc Int Congr Anim Hyg ISAH 2:423-426

Roman A (2010) Levels of copper, selenium, lead, and cadmium in forager bees. Pol J Environ Stud 19(3):663-669

Sadeghi A, Mozafari A-A, Bahmani R, Shokri K (2013) Use of honeybees as bio-indicators of environmental pollution in the Kurdistan Province of Iran. J Agric Sci 56(2):83-88

Shanker AK, Cervantes C, Loza-Tavera H, Avudainayagam S (2005) Chromium toxicity in plants. Environ Int 31(5):739-753

Silva LT, Pinho JL, Nurusman H (2014) Traffic air pollution monitoring based on an air-water pollutants deposition device. Int J Environ Sci Technol 11(8):2307-2318

Sinha S, Guptha M, Chandra P (1997) Oxidative Stress induced by iron in Hydrilla verticillata (i.f) Royle: response of antioxidants. Ecotoxicol Environ Safe 38:286-291

Smolders E, Mertens J (2013) Cadmium. In: Alloway BJ (ed) Heavy metals in soils, 22. Springer, Netherlands, pp 283-311
Tong SSC, Morse RA, Bache CA, Lisk DJ (1975) Elemental analysis of honey as an indicator of pollution. Arch Environ Health 30(7):329-332

Ugulu I, Dogan Y, Baslar S, Varol O (2012) Biomonitoring of trace element accumulation in plants growing at Murat Mountain. Int J Environ Sci Technol 9(3):527-534

Van Der Steen JJM, de Kraker J, Grotenhuis T (2012) Spatial and temporal variation of metal concentrations in adult honeybees (Apis mellifera L.). Environ Monit Assess 184(7):4119-4126

Walker EMJ, Walker SM (2000) Effects of iron overload on the immune system. Ann Clin Lab Sci 30:354-365

Wallwork-Barber MK, Ferenbaugh RW, Gladney ES (1982) The use of honeybees as monitors of environmental pollution. Am Bee $\mathrm{J}$ 122:770-772

Wang YM, Chen TC, Yeh KJ, Shue MF (2001) Stabilization of an elevated heavy metal contaminated site. J Hazard Mater 88(1):63-74

Westfall DG, Mortvedt JJ, Peterson GA, Gangloff WJ (2005) Efficient and environmentally safe use of micronutrients in agriculture. Commun Soil Sci Plant Anal 36(1-3):169-182

Whiley AJ (2011) Copper and zinc loading associated with automotive brake-pad and tire wear, water quality program. Washington State Department of Ecology Olympia, Washington

Wilkinson H (1996) Haemochromatosis associated with arthritis and hypopituitarism. Ann Clin Biochem 333:171-173

Zhelyazkova I, Atanasova S, Barakova V, Mihaylova G (2010) Content of heavy metals and metalloids in bees and bee products from areas with different degree of anthropogenic impact. J Agr Sci Technol 3(1):136-142 